\title{
After Supper
}

National Cancer Institute

\section{Source}

National Cancer Institute. After Supper. NCI Thesaurus. Code C64602.

After supper or evening meal. 